\title{
PEMANFAATAN ANALISA SPASIAL UNTUK KESESUAIAN LAHAN TANAMAN JARAK PAGAR (Studi Kasus: Kabupaten Sumenep Daratan)
}

\author{
Alfian Sukri Rahman, Yuwono, dan Udiana Wahyu Deviantari \\ Jurusan Teknik Geomatika, Fakultas Teknik Sipil dan Perencanaan, \\ Institut Teknologi Sepuluh Nopember Surabaya (ITS) \\ Jl. Arief Rahman Hakim, Surabaya 60111 Indonesia \\ e-mail : yuwono@geodesy.its.ac.id
}

\begin{abstract}
Abstrak
Krisis energi yang melanda dunia termasuk Indonesia menyebabkan terus naiknya harga bahan bakar minyak (BBM). Dengan demikian, tentu suatu saat nanti APBN yang dianggarkan untuk subsidi BBM tidak akan mampu mencukupi karena terus bertambah naiknya harga minyak dunia. Dampak lain dari masalah BBM ini adalah angka kemiskinan di Indonesia khususnya di daerah pedesaan dan daerah terpencil terus meningkat, salah satunya adalah penduduk pedesaan di wilayah Kabupaten Sumenep daratan Provinsi Jawa Timur yang mayoritas bermata pencaharian sebagai petani. Sebagai solusi dari masalah-masalah tersebut, pembudidayaan tanaman jarak pagar dinilai cocok dalam mengatasi masalah kelangkaan BBM dan kemiskinan karena kelebihan-kelebihan yang dimilikinya.
\end{abstract}

Dalam penelitian ini, analisa kesesuaian lahan tanaman jarak pagar di Kabupaten Sumenep daratan dilakukan menggunakan Sistem Informasi Geografis (SIG) dengan mengoverlay peta curah hujan, peta temperatur, peta tekstur tanah, peta elevasi, dan peta kemiringan lereng. Sebelum melakukan overlay, kelima peta tersebut dilakukan penilaian kelas kesesuaian lahan tanaman jarak pagar.

Hasil dari penelitian ini menunjukkan bahwa wilayah Kabupaten Sumenep daratan terbagi dalam 3 kelas kesesuaian lahan, yaitu kelas S2 (cukup sesuai) dengan luas 100152,162 ha, kelas S3 (sesuai marginal) dengan luas 2141,993 ha, dan kelas N (tidak sesuai) dengan luas 12265,207 ha. Dari hasil analisa menunjukkan bahwa terdapat beberapa desa di Kabupaten Sumenep daratan yang wilayahnya tergolong lebih dari satu kelas kesesuaian lahan yang disebabkan oleh faktor elevasi dan kemirigan lereng yang beragam meskipun dalam lingkup satu desa yang sama, faktor pembatas kesesuaian lahan terberat yang mendominasi di tiap desa juga beragam meskipun tergolong dalam jenis kesesuaian lahan yang sama.

Kata Kunci-BBM, Jarak Pagar, Penilaian Kelas Kesesuaian Lahan, SIG.

\section{PENDAHULUAN}

Krisis energi yang melanda dunia termasuk Indonesia menyebabkan kelangkaan bahan bakar minyak (BBM). Ketergantungan Indonesia pada BBM impor semakin memberatkan pemerintah ketika harga minyak dunia terus meningkat, karena semakin besarnya subsidi yang harus diberikan terhadap harga BBM nasional [1]. Kelangkaan BBM ini juga mengakibatkan angka kemiskinan di Indonesia terus mengalami peningkatan khususnya di pedesaan daerah Jawa Timur. Jumlah penduduk miskin di Jawa Timur adalah sebanyak 4,96054 juta (13,08\% dari total jumah penduduk Jawa Timur) [2]. Salah satu daerah yang memiliki angka kemiskinan tinggi di pedesaan adalah Kabupaten Sumenep daratan dengan mayoritas mata pencahariannya adalah bertani. Pengembangan tanaman jarak yang merupakan sumber energi alternatif dinilai sangat cocok untuk menangani masalah-masalah tersebut.

Penelitian ini dilakukan dengan menggunakan SIG dengan mengoverlay peta-peta yang menjadi parameter dalam analisa kesesuaian lahan tanaman jarak pagar yang terdiri dari peta curah hujan tahunan, temperatur, tekstur tanah, elevasi, dan peta kemiringan lereng. Penelitian ini bertujuan untuk menganalisa kesesuaian lahan untuk tanaman jarak pagar dan menyajikan peta kesesuaian lahan tanaman jarak pagar sehingga dapat diketahui daerah-daerah yang cocok untuk tanaman jarak pagar di daerah Kabupaten Sumenep daratan. 


\section{METODOLOGI PENELITIAN}

Lokasi penelitian ini adalah mengambil daerah studi di Kabupaten Sumenep daratan (di wilayah Pulau Madura) yang mempunyai luas $1.146,927065 \mathrm{~km}^{2}$ dan memiliki 18 kecamatan, 242 desa, dan 4 kelurahan [3].
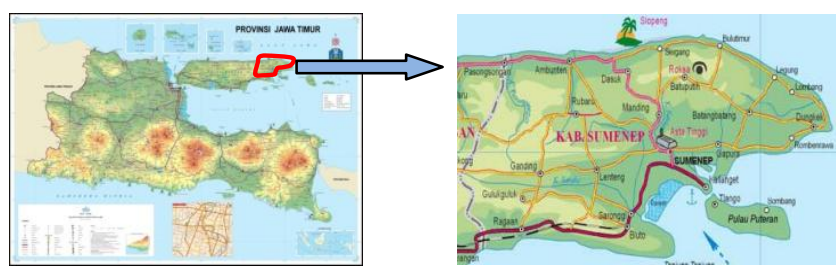

Gambar 1. Lokasi Penelitian [4]

Dalam penelitian ini data yang digunakan adalah 16 Peta RBI digital Kabupaten Sumenep skala 1:25.000 tahun 1998-2001 terbitan BAKOSURTANAL, data curah hujan tahunan $(\mathrm{mm})$ daerah Kabupaten Sumenep tahun 2012, data temperatur tahunan rata-rata $\left({ }^{\circ} \mathrm{C}\right)$ daerah Kabupaten Sumenep tahun 2012, dan data tekstur tanah daerah Kabupaten Sumenep.

Dari data-data tersebut kemudian dilakukan pengolahan data menggunakan software ArcGIS 10 sehingga diperoleh peta curah hujan, peta temperatur, peta tekstur tanah, peta elevasi, dan peta kemiringan lereng. Kemudian dilakukan penilaian kelas kesesuaian lahan (S1, S2, S3, dan N) terhadap kelima peta tersebut. Selanjutnya adalah mengoverlay kelima peta tersebut dan melakukan pengkelasan ulang terhadap hasil dari overlay sehingga diperoleh peta kesesuaian lahan tanaman jarak pagar. Tahap pengolahan data tugas akhir ini ditunjukkan pada diagram alir berikut.

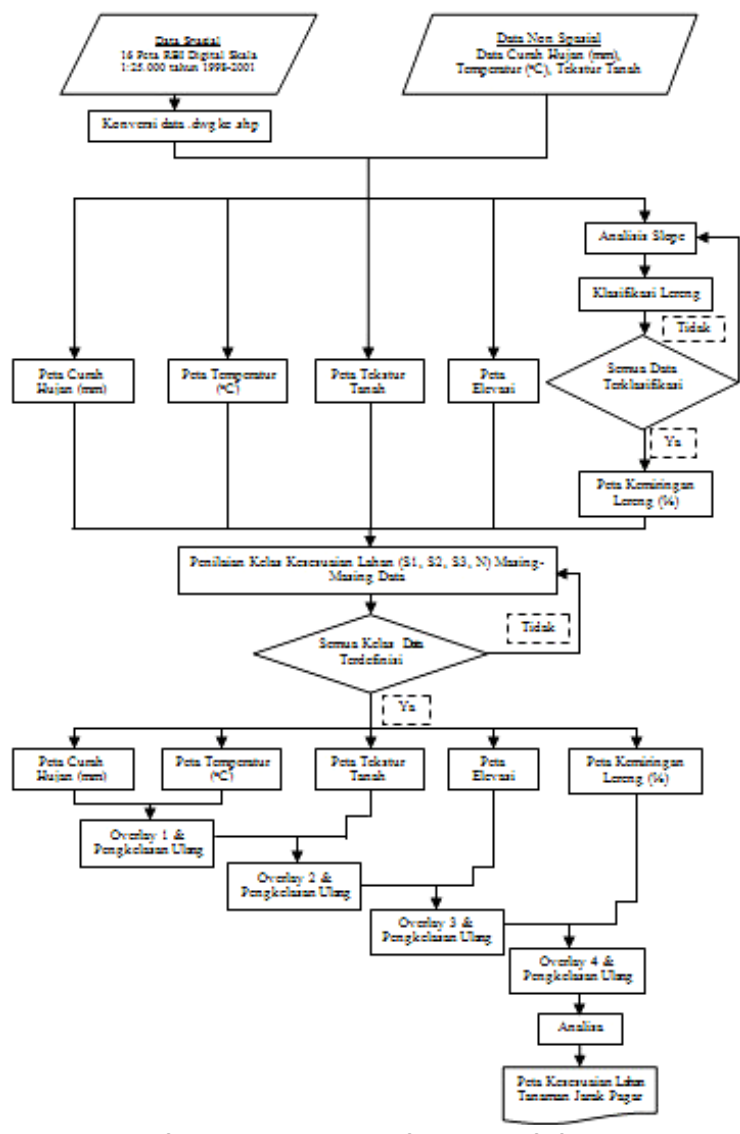

Gambar 2. Diagram Alir Pengolahan Data

\section{HASIL DAN PEMBAHASAN}

Penilaian Kelas Kesesuaian Lahan Tanaman Jarak Pagar Terhadap Pada Peta Curah Hujan, Temperatur, Tekstur Tanah, Elevasi, Dan Kemiringan Lereng

Dari penilaian kelas kesesuaian lahan terhadap peta curah hujan diperoleh hasil bahwa seluruh Kabupaten Sumenep daratan terklasifikasi hanya dalam satu kelas kesesuaian lahan, yaitu kelas S1 (sangat sesuai) dengan curah hujan tahunan sebesar 2208,9 mm. Untuk luas dan persentase masing-masing kelas kesesuian lahan pada peta kelas curah hujan ditampilkan pada tabel berikut.

Tabel 1. Luas Masing-Masing Kelas Kesesuaian Lahan Pada Peta Kelas Curah Hujan

\begin{tabular}{lllr}
\hline \hline No & Kelas Kesesuaian Lahan & Luas $(\mathrm{Ha})$ & $\%$ \\
\hline 1. & S1 (sangat sesuai) & 114559,362 & 100 \\
2. & S2 (cukup sesuai) & 0 & 0 \\
3. & S3 (sesuai marginal) & 0 & 0 \\
4. & N (tidak sesuai) & 0 & 0 \\
Jumlah & & 114559,362 & 100 \\
\hline \hline
\end{tabular}


Untuk penilaian kelas kesesuaian lahan terhadap peta temperatur diperoleh hasil bahwa seluruh Kabupaten Sumenep daratan terklasifikasi hanya dalam satu kelas kesesuaian lahan, yaitu kelas S2 (cukup sesuai) dengan temperatur tahunan ratarata sebesar $28,1^{\circ} \mathrm{C}$. Untuk luas dan persentase masing-masing kelas kesesuian lahan pada peta kelas temperatur ditampilkan pada tabel berikut.

Tabel 2. Luas Masing-Masing Kelas Kesesuaian Lahan Pada Peta Kelas Temperatur

\begin{tabular}{llcr}
\hline \hline No & Kelas Kesesuaian Lahan & Luas $(\mathrm{Ha})$ & $\%$ \\
\hline 1. & S1 (sangat sesuai) & 0 & 0 \\
2. & S2 (cukup sesuai) & 114559,362 & 100 \\
3. & S3 (sesuai marginal) & 0 & 0 \\
4. & N (tidak sesuai) & 0 & 0 \\
Jumlah & & 114559,362 & 100 \\
\hline \hline
\end{tabular}

Dari penilaian kelas kesesuaian lahan yang dilakukan terhadap peta tekstur tanah diperoleh hasil bahwa wilayah Kabupaten Sumenep daratan terklasifikasi dalam 4 kelas kesesuaian lahan, yaitu S1 untuk tekstur tanah halus, agak halus, dan agak kasar, S2 untuk tekstur tanah sedang, S3 untuk tekstur tanah sangat halus, dan $\mathrm{N}$ untuk tekstur tanah kasar. Untuk luas dan persentase masing-masing kelas kesesuian lahan pada peta kelas tekstur tanah ditampilkan pada tabel berikut.

Tabel 3. Luas Masing-Masing Kelas Kesesuaian Lahan Pada Peta Kelas Tekstur Tanah

\begin{tabular}{llcc}
\hline \hline No & Kelas Kesesuaian Lahan & Luas $(\mathrm{Ha})$ & $\%$ \\
\hline 1. & S1 (sangat sesuai) & 69771,552 & 60,904 \\
2. & S2 (cukup sesuai) & 30685,150 & 26,785 \\
3. & S3 (sesuai marginal) & 1837,939 & 1,604 \\
4. & N (tidak sesuai) & 12264,721 & 10,707 \\
Jumlah & & 114559,362 & 100 \\
\hline \hline
\end{tabular}

Dari penilaian kelas kesesuaian lahan terhadap peta elevasi diperoleh hasil bahwa wilayah Kabupaten Sumenep daratan terklasifikasi dalam 2 kelas kesesuaian lahan, yaitu

1) S1 (sangat sesuai).

Dalam peta kelas elevasi, yang tergolong dalam kelas S1 meliputi: $0-400 \mathrm{~m}$ dpl.

2) S2 (cukup sesuai).

Elevasi yang tergolong dalam kelas S2 adalah elevasi dengan interval $400-500 \mathrm{~m} \mathrm{dpl}$.
Untuk luas dan persentase masing-masing kelas kesesuian lahan pada peta kelas elevasi ditampilkan pada tabel berikut.

Tabel 4. Luas Masing-Masing Kelas Kesesuaian Lahan Pada Peta Kelas Elevasi

\begin{tabular}{llcc}
\hline \hline No & Kelas Kesesuaian Lahan & Luas $(\mathrm{Ha})$ & $\%$ \\
\hline 1. & S1 (sangat sesuai) & 114481,561 & 99,933 \\
2. & S2 (cukup sesuai) & 77,801 & 0,067 \\
3. & S3 (sesuai marginal) & 0 & 0 \\
4. & N (tidak sesuai) & 0 & 0 \\
Jumlah & & 114559,362 & 100,000 \\
\hline \hline
\end{tabular}

Dari penilaian kelas kesesuaian lahan terhadap peta kemiringan lereng diperoleh hasil bahwa wilayah Kabupaten Sumenep daratan terklasifikasi dalam 3 kelas kesesuaian lahan, yaitu

1) S1 (sangat sesuai)

Yang tergolong dalam kelas S1 adalah kemiringan lereng $<15 \%$.

2) S2 (cukup sesuai)

Yang tergolong dalam kelas S2 adalah kemiringan lereng $15-30 \%$.

3) S3 (sesuai marginal)

Yang tergolong dalam kelas S3 adalah kemiringan lereng $30-40 \%$.

Untuk luas dan persentase masing-masing kelas kesesuian lahan pada peta kelas kemiringan lereng ditampilkan pada tabel berikut :

Tabel 5. Luas Masing-Masing Kelas Kesesuaian Lahan Pada Peta Kelas Kemiringan Lereng

\begin{tabular}{llcc}
\hline \hline No & Kelas Kesesuaian Lahan & Luas $(\mathrm{Ha})$ & $\%$ \\
\hline 1. & S1 (sangat sesuai) & 110621,178 & 99,932 \\
2. & S2 (cukup sesuai) & 3622,987 & 3,163 \\
3. & S3 (sesuai marginal) & 315,197 & 0,275 \\
4. & N (tidak sesuai) & 0 & 0 \\
Jumlah & & 114559,362 & 100,000 \\
\hline \hline
\end{tabular}

Perbandingan Hasil Analisa Kesesuaian Lahan Tanaman Jarak Pagar Dengan Penelitian Lain Setelah diperoleh hasil dari analisa kesesuaian lahan tanaman jarak pagar di Kabupaten Sumenep daratan, maka perlu dilakukan pengecekan kebenaran (validasi) terhadap hasil tersebut, salah satu caranya adalah dengan melakukan perbandingan hasil penelitian ini yang berupa peta kesesuaian lahan tanaman jarak pagar dengan penelitian lain. Penelitian lain tersebut dilakukan oleh IIman Nafian D (2007) dengan judul "Kajian Parameter Iklim Wilayah 
Jawa Timur Untuk Mencari Area Potensial Tanaman Jarak Pagar Berbasis Sistem Informasi Geografis".

Data utama yang digunakan adalah data observasi BMG untuk wilayah Jawa Timur (berupa data bulanan dari curah hujan, temperatur, dan radiasi matahari) mulai tahun 1971 hingga tahun 1985 dan citra satelit SRTM wilayah Jawa Timur.

Dari penelitian tersebut diperoleh hasil bahwa hanya sebagian kecil daerah di Kabupaten Sumenep yang potensial ditanami tanaman jarak pagar.

Terdapat beberapa faktor yang menyebabkan perbedaan hasil antara penelitian ini dengan penelitian lain, yaitu:

Perbedaan data curah hujan dan temperatur yang digunakan untuk kedua penelitian tersebut. Penelitian ini menggunakan curah hujan dan temperatur tahun 2012, sedangkan penelitian lain menggunakan data curah hujan dan temperatur tahun 1971-1985. Perbedaan tahun data antara kedua penelitian tersebut mengakibatkan nilai curah hujan dan temperatur yang berbeda mempengaruhi hasil dari klasifikasi area yang sesuai untuk tanaman jarak pagar.

Perbedaan parameter yang digunakan dalam penelitian. Untuk penelitian ini menggunakan parameter curah hujan, temperatur, tekstur tanah, elevasi, dan kemiringan lereng. Sedangkan penelitian lain tersebut menggunakan parameter curah hujan, temperatur, radiasi matahari, dan elevasi. Perbedaan parameter yang digunakan sangat mempengaruhi hasil analisa kesesuaian lahan, hal ini berhubungan dengan ketentuan pengkelasan ulang terhadap hasil overlay seperti yang terdapat pada tabel 2.1 di bagian kajian pustaka. Sebagai contoh, misalnya dari penilaian kesesuaian lahan terhadap radiasi matahari diperoleh hasil bahwa seluruh wilayah Kabupaten Sumenep tidak sesuai untuk tanaman jarak pagar. Maka apabila radiasi matahari tersebut dijadikan sebagai parameter dalam penelitian ini maka hasil dari penelitian ini akan menjadi seluruh wilayah Kabupaten Sumenep daratan tidak sesuai untuk tanaman jarak pagar. Padahal sebelum radiasi matahari digunakan sebagai parameter dalam penelitian ini, sebagian besar wilayah Kabupaten Sumenep sesuai untuk tanaman jarak pagar.

Perbedaan acuan yang digunakan untuk melakukan penilaian kesesuaian lahan tanaman jarak pagar terhadap parameter-parameter kesesuaian lahan. Dalam penelitian ini, acuan penilaian kesesuaian lahan yang digunakan adalah kriteria kesesuaian lahan menurut Mulyani tahun 2007 dan 2006 seperti yang ditunjukkan pada tabel 2.2 dan tabel 2.3 di bagian tinjauan pustaka. Sedangkan penelitian lain tersebut menggunakan acuan syarat tumbuh tanaman jarak pagar menurut Hambali Elrliza dkk (2006)

Jika diteliti, perbedaan dari kedua acuan tersebut adalah dalam hal temperatur udara rata-rata dan curah hujan tahunan. Hal ini berpengaruh terhadap proses penilaian kesesuaian lahan terhadap tiap parameter yang digunakan. Sebagai contoh yaitu penilaian kesesuaian lahan terhadap temperatur rata-rata Kabupaten Sumenep tahun 2012 yang mempunyai nilai 28,1 ${ }^{\circ} \mathrm{C}$, maka tergolong cukup sesuai menurut tabel kriteria kesesuaian lahan tanaman jarak pagar pada tabel 2.2. Tetapi jika penilaian kesesuaian lahan dilakukan dengan menggunakan acuan dalam penelitian lain, maka temperatur rata-rata $28,1{ }^{\circ} \mathrm{C}$ tidak sesuai untuk tanaman jarak pagar.

Hasil Analisa Luas Masing-Masing Kelas Kesesuaian Lahan Tanaman Jarak Pagar

Dari hasil analisa kesesuaian lahan untuk tanaman jarak pagar di wilayah Kabupaten Sumenep daratan, diperoleh luas dari masingmasing kelas kesesuaian lahan. Berikut ini tabel dari luas masing-masing kelas kesesuaian lahan.

Tabel 6. Luas Masing-Masing Kelas Kesesuaian Lahan Tanaman Jarak Pagar

\begin{tabular}{llr}
\hline \hline No & Kelas Kesesuaian Lahan & Luas (Ha) \\
\hline 1. & S1 (sangat sesuai) & 0 \\
2. & S2 (cukup sesuai) & 100152,648 \\
3. & S3 (sesuai marginal) & 2141,993 \\
4. & N (tidak sesuai) & 12264,721 \\
Jumlah & & 114559,362 \\
\hline \hline
\end{tabular}

Berikut ini adalah persentase dari luas masingmasing kelas kesesuaian lahan tanaman jarak pagar. 


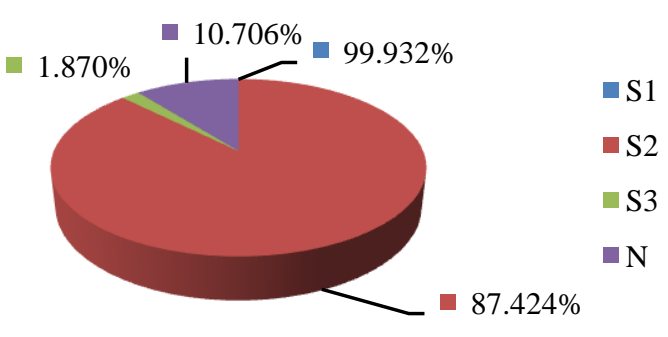

Gambar 3. Persentase Luas Masing-Masing Kelas Kesesuaian Lahan Tanaman jarak Pagar

Hasil Analisa Faktor Pembatas Terberat Dalam Kesesuaian Lahan Tanaman Jarak Pagar Di Tiap Desa Wilayah Kabupaten Sumenep Daratan

Yang ditentukan sebagai faktor pembatas terberat di tiap desa adalah parameterparameter yang tergolong dalam kelas kesesuaian lahan terendah yang luasnya mendominasi kelas kesesuaian lahan lainnya. Jadi dalam hal ini faktor luasan dari masing-masing kelas kesesuian lahan juga diperhitungkan. Apabila dalam suatu desa terdapat parameter yang tergolong dalam kelas kesesuaian lahan terendah tetapi luasnya hanya sebagian kecil dari luas keseluruhan desa tersebut, maka parameter kesesuaian lahan tersebut bukan merupakan faktor pembatas yang terberat. Karena di Kabupaten Sumenep daratan terdapat 242 desa dan 4 kelurahan, maka berikut ini hanya disajikan tabel dari hasil analisa faktor pembatas terberat kesesuaian lahan di beberapa desa bukan seluruh desa yang berada di wilayah Kabupaten Sumenep Daratan.

\begin{tabular}{|l|l|l|l|l|l|}
\hline \multirow{2}{*}{ Desa / Kelurahan } & \multicolumn{5}{l}{ Faktor Pembatas Terberat } \\
\cline { 2 - 7 } & $\begin{array}{l}\text { Curah } \\
\text { Hujan }\end{array}$ & Suhu & $\begin{array}{l}\text { Tekstur } \\
\text { Tanah }\end{array}$ & Elevasi & Slope \\
\hline Aeng Daka & - & $\mathrm{V}$ & $\mathrm{V}$ & - & $\mathrm{V}$ \\
\hline Aeng Merah & - & $\mathrm{V}$ & $\mathrm{V}$ & - & - \\
\hline Aeng Panas & - & $\mathrm{V}$ & $\mathrm{V}$ & - & $\mathrm{V}$ \\
\hline Aeng Baja Kenek & - & $\mathrm{V}$ & $\mathrm{V}$ & - & - \\
\hline Aeng Baja Raja & - & $\mathrm{V}$ & - & - & - \\
\hline Aeng Tongtong & - & $\mathrm{V}$ & - & - & - \\
\hline Duko & - & $\mathrm{V}$ & - & - & $\mathrm{V}$ \\
\hline Dungkek & - & $\mathrm{V}$ & - & - & - \\
\hline Ellak Daya & - & $\mathrm{V}$ & $\mathrm{V}$ & - & $\mathrm{V}$ \\
\hline Ellak Laok & - & $\mathrm{V}$ & $\mathrm{V}$ & - & $\mathrm{V}$ \\
\hline Errabu & - & $\mathrm{V}$ & - & - & - \\
\hline Gadding & - & - & $\mathrm{V}$ & - & - \\
\hline Gading & - & $\mathrm{V}$ & - & - & - \\
\hline Gadu Barat & - & $\mathrm{V}$ & - & - & $\mathrm{V}$ \\
\hline Gadu Timur & - & $\mathrm{V}$ & - & - & $\mathrm{V}$ \\
\hline Banasare & - & - & $\mathrm{V}$ & - & - \\
\hline Bangkal & - & $\mathrm{V}$ & - & - & - \\
\hline
\end{tabular}

\begin{tabular}{|l|l|l|l|l|l|}
\hline Bantelan & - & V & - & - & - \\
\hline Banuaju Barat & - & V & V & - & - \\
\hline Banuaju Timur & - & V & V & - & - \\
\hline Baringin & - & V & - & - & - \\
\hline Batuampar & - & - & - & - & V \\
\hline Batuan & - & V & - & - & - \\
\hline Batuputih Daya & - & V & - & - & V \\
\hline Batuputih Kenek & - & V & - & - & - \\
\hline Batuputih Laok & - & V & - & - & - \\
\hline Bakeyong & - & V & V & - & V \\
\hline
\end{tabular}

Keterangan: $\mathrm{V}=\mathrm{Ya},-=$ Tidak

\section{KESIMPULAN DAN SARAN}

Berdasarkan hasil penelitian tentang analisa kesesuaian lahan tanaman jarak pagar di Kabupaten Sumenep daratan, maka didapatkan beberapa kesimpulan akhir dari penelitian ini, yaitu:

Wilayah Kabupaten Sumenep daratan terbagi dalam 3 kelas kesesuaian lahan untuk tanaman jarak pagar, yaitu S2 (cukup sesuai), S3 (sesuai marginal), dan $\mathrm{N}$ (tidak sesuai.

Luas masing-masing kelas kesesuaian lahan tanaman jarak pagar di Kabupaten Sumenep adalah 100152,648 ha untuk kelas S2, 2141,993 ha untuk kelas S3, dan 12264,721 ha untuk kelas N.

\section{LAMPIRAN}

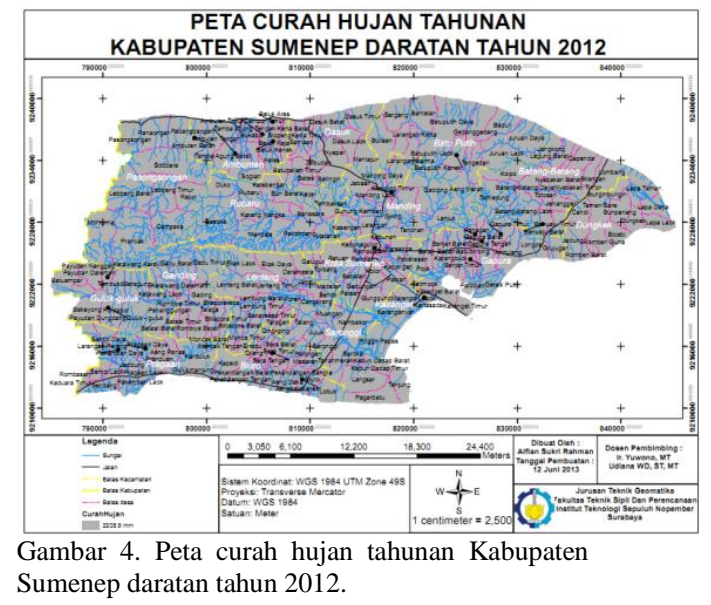




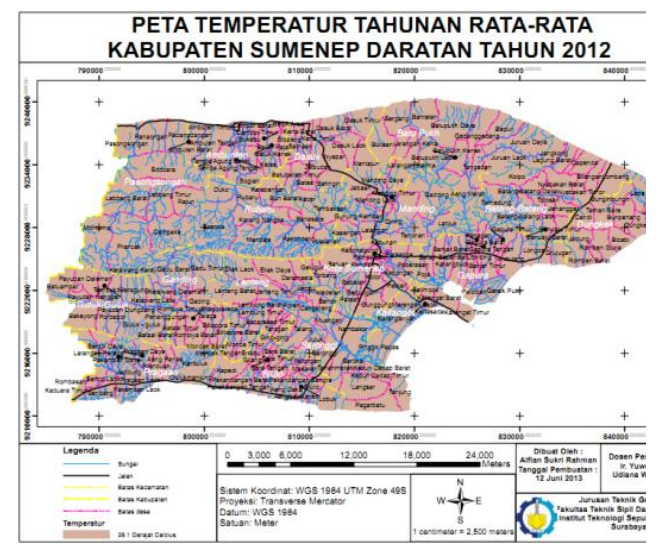

Gambar 5. Peta temperatur tahunan rata-rata

Kabupaten Sumenep daratan tahun 2012.

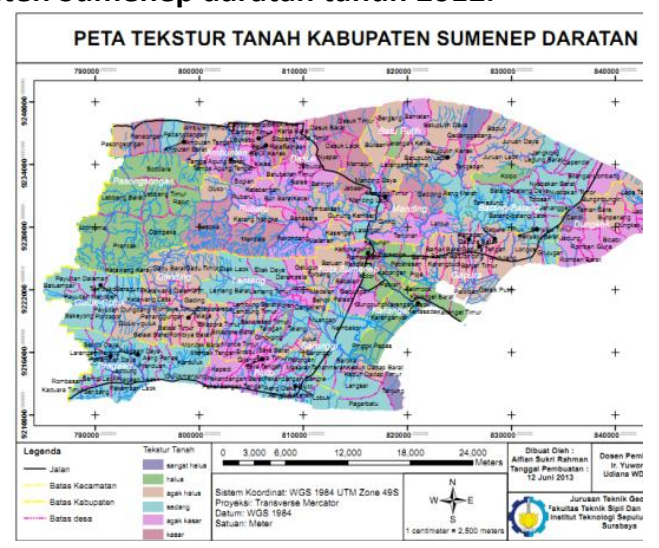

Gambar 6. Peta tekstur tanah Kabupaten Sumenep daratan.

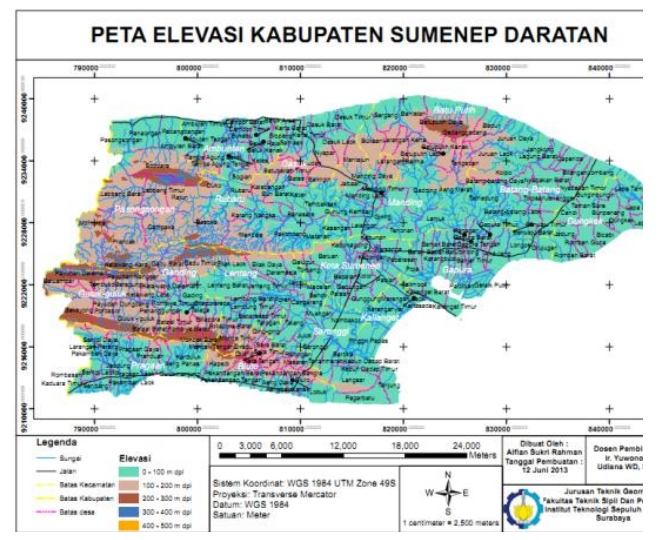

Gambar 7. Peta elevasi Kabupaten Sumenep daratan.

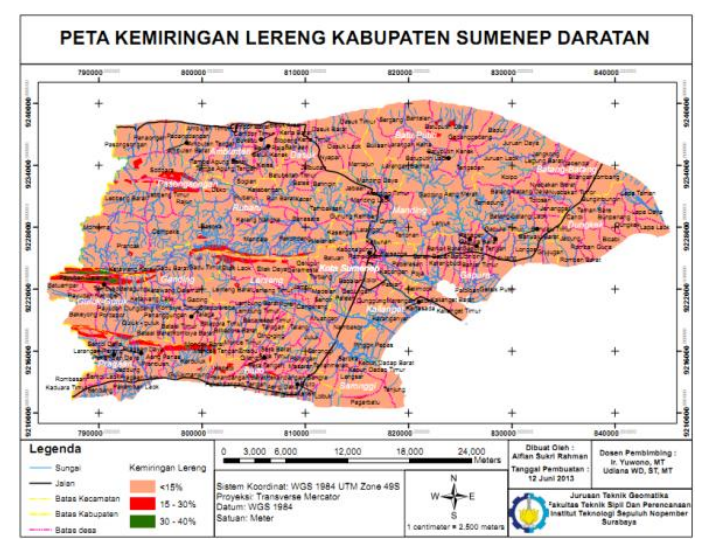

Gambar 8. Peta Kemiringan Lereng Kabupaten Sumenep daratan.

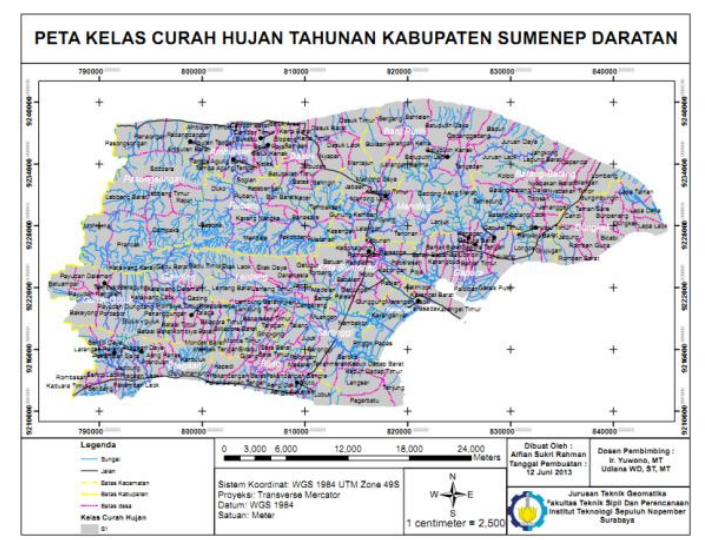

Gambar 9. Peta kelas curah hujan Kabupaten Sumenep daratan.

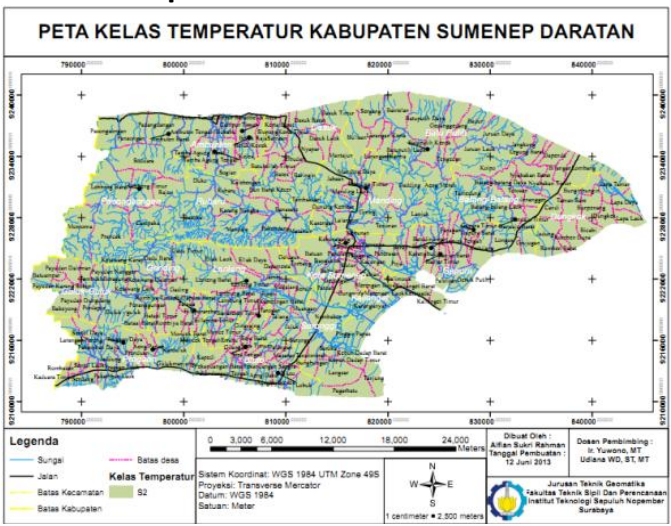

Gambar 10. Peta kelas temperatur Kabupaten Sumenep daratan. 


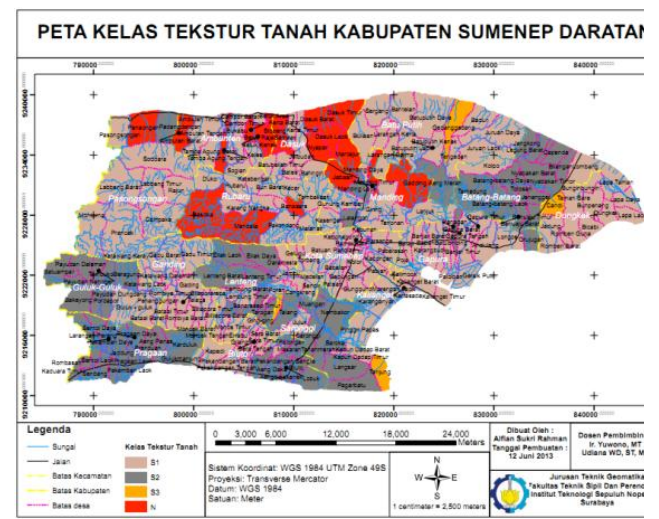

Gambar 11. Peta kelas tekstur tanah Kabupaten Sumenep daratan.

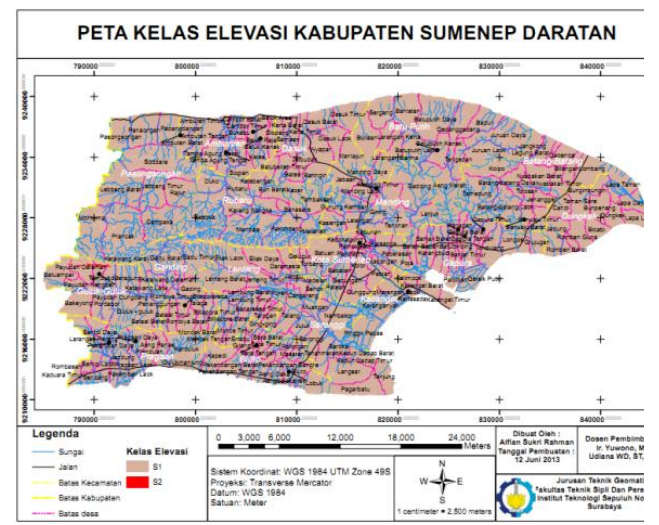

Gambar12. Peta kelas elevasi Kabupaten Sumenep daratan.

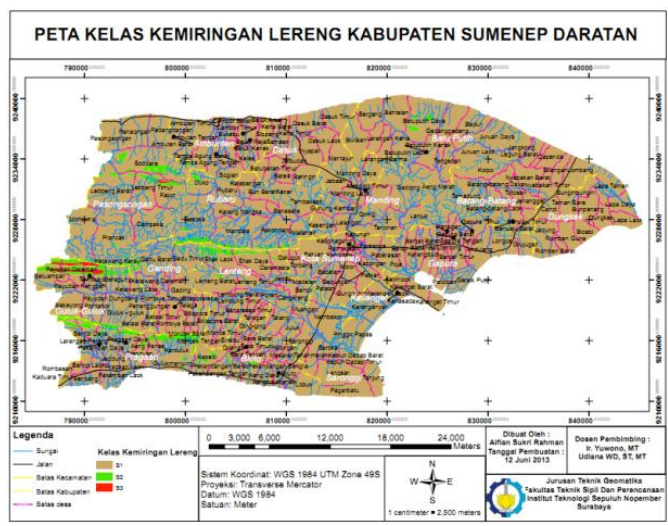

Gambar 13. Peta kelas kemiringan lereng Kabupaten Sumenep Daratan.

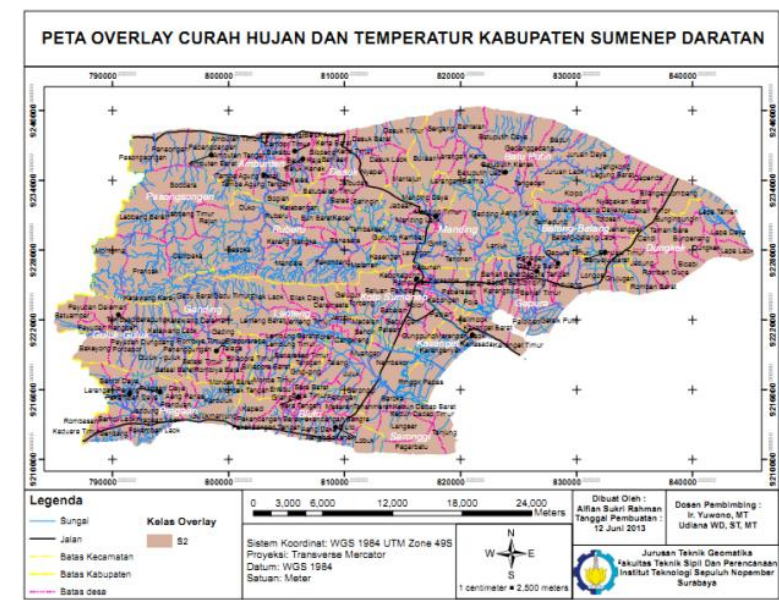

Gambar 14. Peta overlay curah hujan dan temperatur Kabupaten Sumenep daratan.

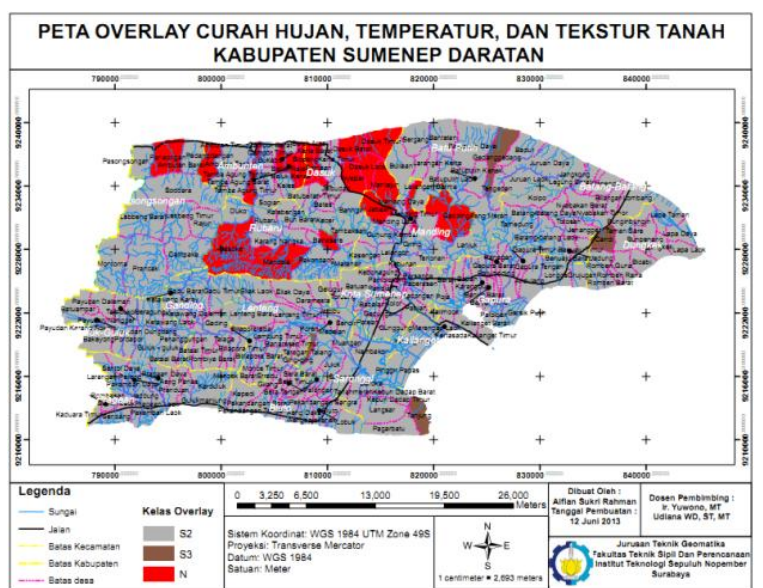

Gambar 15. Peta overlay curah hujan, temperatur, dan tekstur tanah Kabupaten Sumenep daratan.

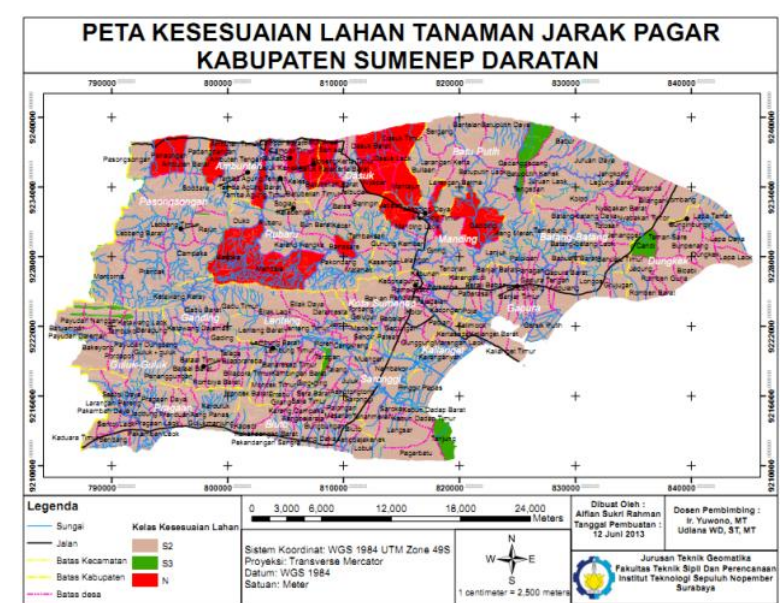

Gambar 17. Peta kesesuaian lahan tanaman jarak pagar Kabupaten Sumenep daratan. 


\section{DAFTAR PUSTAKA}

Ardana, I.K., dkk, 2008. “Pengembangan Tanaman Jarak Pagar (Jatropha Curcas L) Mendukung Kawasan Mandiri Energi Di Nusa Penida, Bali”. Jurnal Littri 14(4), Desember2008. HIm. 155-161.

Badan Pusat Statistik. 2013. Profil Kemiskinan Di Jawa Timur September 2012, Available: http://jatim.bps.go.id/index.php/pelayan an-statistik/brs-jawa-timur/brs

kemiskinan-jatim/256--profil-kemiskinandi-jawa-timur-september-2012.

Letak Geografis Kabupaten Sumenep. Available: http://www.sumenep.go.id/?page=geogr afis.html>.

http:// 